\title{
Online Business Training To Teenagers "Shelter Rumah Hati " For Ex-Prisoners
}

\author{
Nur Alinda Wati ${ }^{*}$, Pinkan Amita Tri Prasasti ${ }^{2}$, Tiyas Hartika Putri ${ }^{3}$, Hayu Diyaning Ratri ${ }^{4}$ \\ 1,2,3,4 Primary School Teacher Education, Universitas PGRI Madiun
}

\section{A R T I C L E I N F O}

Article history:

Received 19 Januari 2018

Received in revised form

12 Februari 2018

Accepted 28 Maret 2018

Available online $20 \mathrm{Mei}$

2018

Keywords:

Shelter Rumah Hati, Online

business, ex-prisoner
A B S T R A C T

Community service team of Teachers Elementary School Education of PGRI University Madiun has conducted Online Business Training to Children and Youth Shelter Rumah Hati in Jombang. Shelter Rumah Hati is a place for ex-narapida children who have just come out of prisons and given mentoring there. The purpose of community service is: 1) To give knowledge about how to do business online to former inmates in Jombang House of the Heart, so they can open the job for themselves or others. 2) To provide assistance to children and adolescents who are in Shelter Rumah Hati Jombang. 3) To provide online-based skills to children and adolescents at Jombang Home Shelter. This training activity begins by meeting the shelter to seek permission to conduct online business training activities. We further deliver general material submissions on online business using lecture methods. After the delivery of materials, conducted activities of business practices online. After practice the way of our online business do mentoring process. The results of the training show that children and adolescents who are in Shelter Rumah Hati have a very high interest in online business, this can be seen from the questionnaire that we distributed to the children and adolescents there, they fill the satisfaction questionnaire with the value of the conversion of 87.8 means very good. Evaluation results related to the effectiveness of training also increased based on the $\mathrm{N}$-Hake criteria with a value of 0.74 which means very good. Online Business Training at Jombang House Shelter in children and teenagers can be summed up that are interested and have the potential to open an online business.

\footnotetext{
* Corresponding author.

E-mail addresses: nuralinda07@gmail.com (Nur Alinda Wati)
} 



\section{Introduction}

In general, many people still have a negative view of the figure of former inmates. Prisoners by the community are regarded as trouble makers or riot makers who are always disturbing the community so that people reject and be aware of them. The attitude of the community's refusal to make the prisoners have difficulty in resocialization in the community. And what happens at the moment is, there are still many people in the community who do not care and exclude the presence of former inmates to be part of the members in community life.

Difficulties experienced by inmates, among others, to regain the confidence of the surrounding community and difficulties in obtaining employment. It's hard for the ex-prisoner to go back to the community, or to be afraid of being excommunicated and humiliated by others. Because they feel inferior, and do not have a high belief that he is also a human being created to socialize to the environment. From this it is necessary to know how the attitude of optimism for the future of inmates who still undergo a period of punishment in the face of freedom or after completion of the sentence. Because humans as social beings, can not live alone to meet the needs of his life. Humans will definitely need others to be able to grow and need each other and influence each other.

In Jelak Ombo Jombang Village, there is a social institution, Shelter Rumah Hati, who assisted and nurtured children and adolescents who had just stepped out of Penitentiary from Jombang prison, Blitar prison and Rutan Medaeng. This institution instills the values of Islamic education to former child prisoners, especially in worship. Shelter Rumah Hati is an institution that provides a place for children to stay temporarily after coming out of prison. For 3 to 6 months they will get psychological counseling and provide skills so that they can return to the community. It is hoped that with the provision of skills such as motor, computer, arts, and arts training skills, children and adolescents are able to be self-sufficient both economically and personally when returning to the community. And economic independence will provide a valuable feeling that will minimize the possibility of the child repeating his actions again. Shelter Rumah Hati Jombang only provides skills that are common to children and adolescents.

In the age of globalization like today and increasingly sophisticated technology, online-based business is very rampant among the 2 ordinary people. Online business is an activity or activity that is done in the internet media to make money. Just like a business activity in real life, online business that run via the Internet also has the same goal that is generating a profit. Along with the development of online business, it is also not impossible many people who depend from this sector of life. Not just as a side business, but many people are using online business as the main business. As a result, online businesses have so far scored thousands of successful and successful businesses.

Therefore PGRI Madiun University team in the process of dedication to the community held an online business related training against former teenage prisoners who are in Shelter Rumah Hati Jelak Village, Jombang, East Java. To train ex-inmate teenagers doing business online to get them a decent job and not minder in the community environment.

\section{Method}

Online Business Activity Training for Youth at Shelter Rumah Hati located in Dusun Jelak Ombo Jombang, was held for 4 months. The method undertaken in this program through 4 stages namely situation analysis, preparation, implementation and evaluation. Here are the steps: 


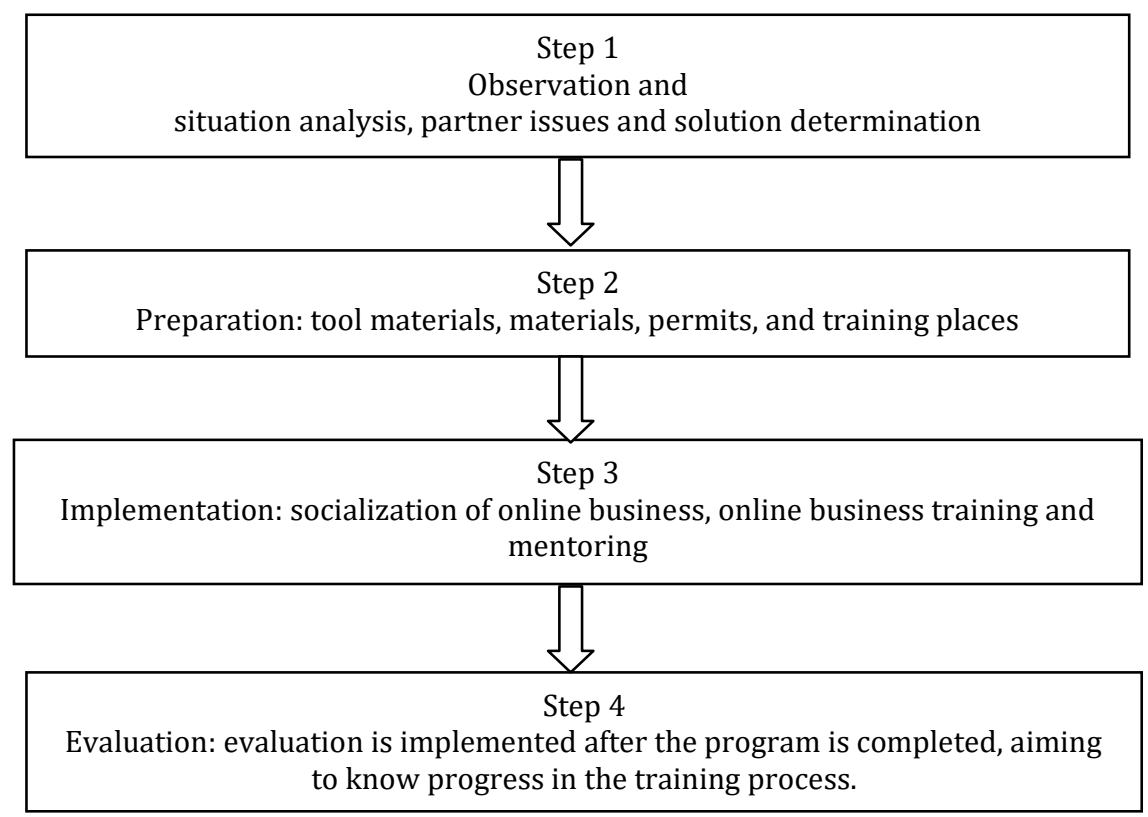

Figure 1. Flow Chart of Online Business Training Implementation

Evaluation activities undertaken aims to determine the progress and effectiveness of the training and assistance provided. Evaluation is done by giving questionnaire of satisfaction as well as intruments test to measure the ability of the absorption of material related to online business. The results of the evaluation into a picture, to develop the program and further training.

\section{Discussion}

Online business training for youth home shelters for former inmates in Hamlet Jelak Ombo Jombang "was carried out with 3 stages, namely stage 1 (preparation), including consultation of proposal with supervisor, determining resource person as supporter of training program and observation to Shelter Rumah Hati Jombang. Phase 2 (implementation) includes socialization of online business, online business training and mentoring. Stage 3 (evaluation) is intended to know the extent of knowledge and understanding of children against doing business online.

\section{Stage 1. Situation Analysis}

Implementation of PKM-M activity started from observation to Shelter Rumah Hati Jombang on April 13, 2018. Observation activity was done to see the situation of children and adolescents who are in Shelters Rumah Hati in Jelak Village, and ask permission to conduct PKM-M activities there with the title "Online business training to children and teenager Shelter Home for Former Prisoners in Hamlet Jelak Ombo Jombang" which aims to facilitate the team in planning the program PKM devotion to be implemented.

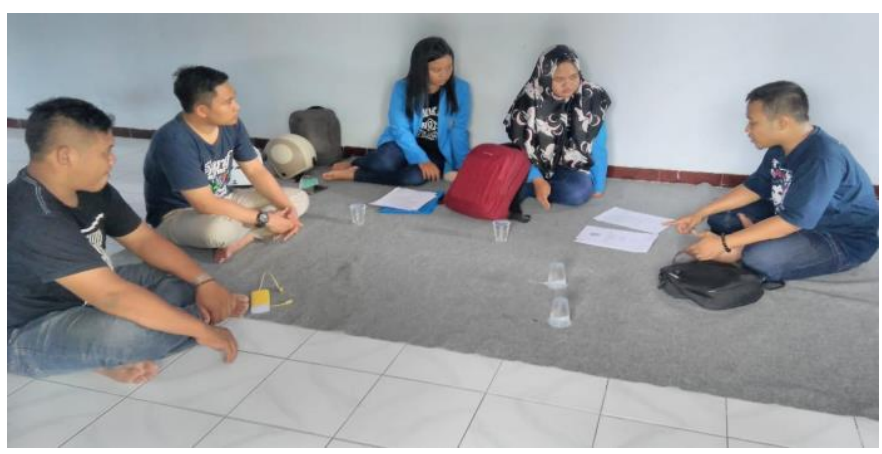

Figure 3. Observation and Situation Analysis Stage 


\section{Stage 2. Preparation}

The preparation stage is divided into 3 stages:

1. Preparing equipment and equipment used during the training, taking care of the permit letter during the activities to run smoothly, preparing the training ground

2. prepare material and team of experts to strengthen training of the team of devotion in training and give wider insight to us, children and adolescents who are in Shelter Rumah Hati Jombang.

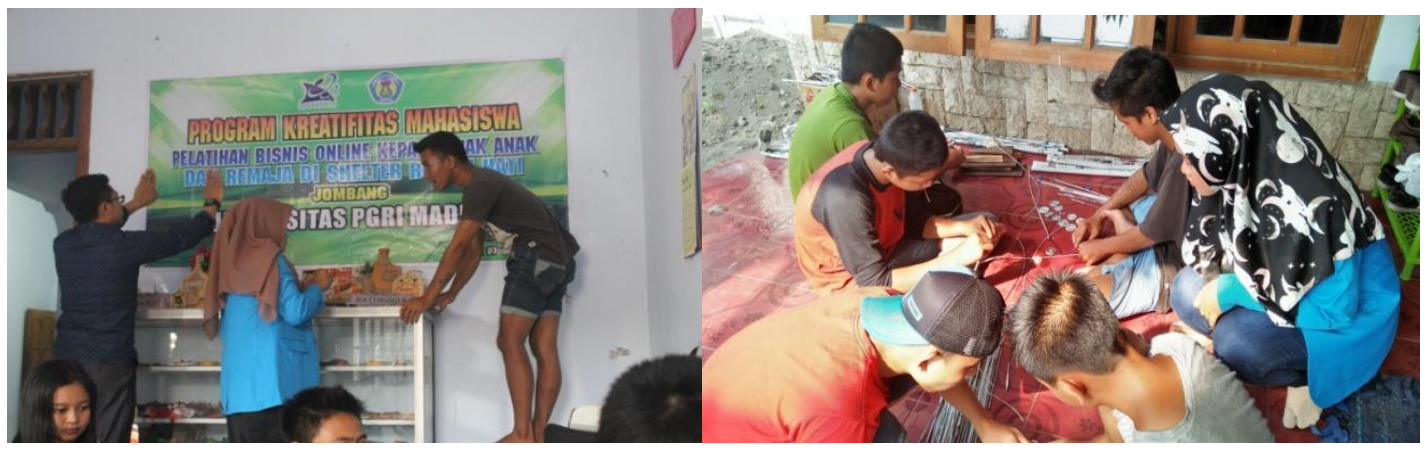

Figure 4. Training Preparation Activities

\section{Stage 3. Implementation}

The implementation stage is divided into 3 stages, namely:

1. Socialization Stage.

The socialization stage was held on April 28, 2018, the stage of socialalilation is the general stage of material delivery. The first activity is to socialize everything related to online business such as what is meant to do online business, purpose, benefit and how to do business online, and explain our intent and purpose to children and teenagers who are in Shelter Rumah Hati Jombang to participate in this activity. The material delivered packed using media power point so that practical and easy to understand by the children and adolescents who are in Shelter Rumah Hati.

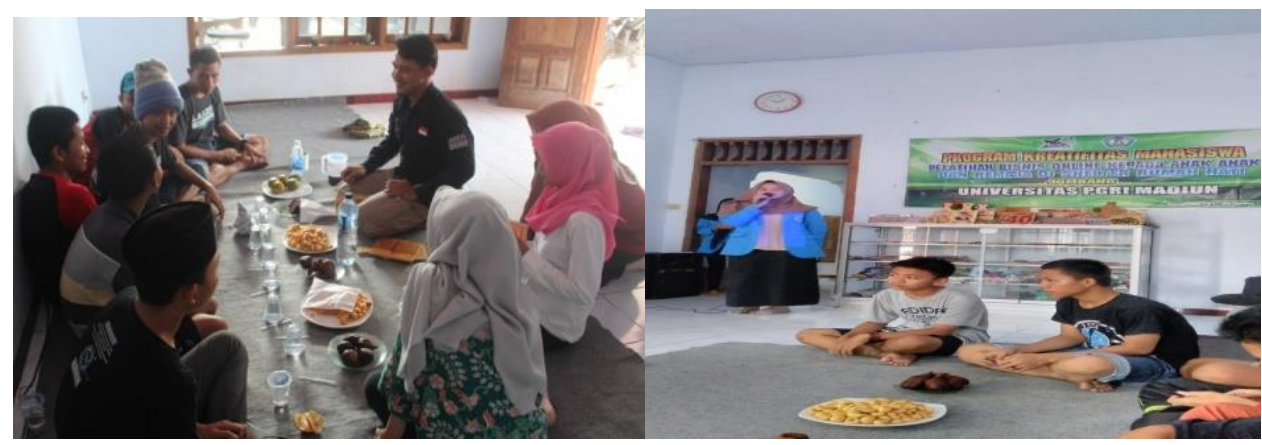

2. Training Stage.

Figure 3. Socialization of Program Activities

Training phase or stage of applying practice was conducted on April 29, 2018. Conduct training or practice directly to children and adolescents who are in Shelter Rumah Hati Jombang. In this training will be attended by approximately 20 children and adolescents who are in Shelter Rumah Hati Jombang by conducting training to children and adolescents starting from the beginning of introduction about doing business online to marketing or targeted target for wider community and make sure child children and teenagers really understand what has been conveyed.

3. Stage Assistance. In our training activities we provide assistance to monitor and direct the training process to run smoothly and ensure that they are fully prepared to do business online independently. From the members of our group all follow the accompaniment stage to accompany the children and adolescents who are in Shelter Rumah Jati Jombang. 


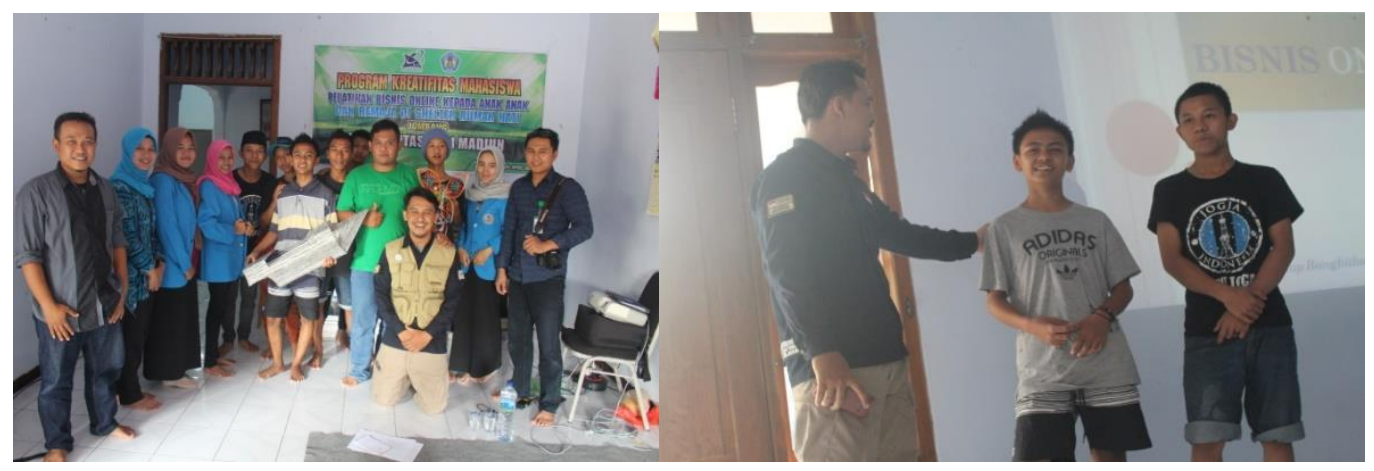

Stage 4. Evaluation

Figure. 5 Stage Training and Assistance

Evaluation of the program is carried out after this activity is completed, it is intended that after the participants attended this training can immediately know the level of understanding and competence of the participants and ensure that trainees are able to do business online in accordance with the outcome that the team expected. Based on the satisfaction questionnaire that we distributed to children and adolescents who are in Jombang House Shelter is $100 \%$ interested to do business online in the future, because after we submit their material antusia to open an online business there who want to open motorcycle parts business, selling his services or abilities such as lectures or tausyiah, and some who want to open an online business about farms, that is farm based online.

Table 1. Evaluation Results.

\begin{tabular}{ccc}
\hline Participants & $\begin{array}{c}\text { Pre- Mastery of Online } \\
\text { Business }\end{array}$ & $\begin{array}{c}\text { Post- Mastery of Online } \\
\text { Business }\end{array}$ \\
\hline 1 & 60 & 40 \\
80 \\
2 & 55 & 82 \\
3 & 40 & 78 \\
5 & 62 & 83 \\
6 & 65 & 85 \\
7 & 50 & 84 \\
\hline
\end{tabular}

Based on the evaluation results seen improvements in the skills of participants in developing the online business, obtained an average increase with the criteria of $\mathrm{N}$-hake very good that is 0.74 . Online business training is a priority for the team as it sees the current phenomenon of using Information Technology to help communities in areas such as commerce and entrepreneurship as a source of information and as a means to promote and market their products, one of them through online trading. Community empowerment in the economic field with the use of IT for business has become a phenomenon today with the rise of Internet-based online business. Utilization of the internet for online business is widely used because it is more flexible to run the business from home so it does not require recognition from the workplace and company. IT Utilization should not be intended for large-scale companies.

According to the economic census (BPS 2006) shows the number of SMEs about 22,513,552. But in 2008 the number of Micro, Small and Medium Enterprises was 46 million. Of 46 million users almost $80 \%$ utilize the role of online network, with that amount, the role of technology utilization becomes big enough for economic resilience because it can create job field. To anticipate the impact of globalization, public understanding, especially for the ex-prisoner community on the benefits of information technology should be improved. This is considered important to compensate for potential changes. To support such activities trainings to prisoners of prisoners on the use of information technology in business must be improved. The participation of women in economic enterprises is fully supported by Law No.11 / 2005 on the ratification of economic, social and cultural rights and Law no. 12/2005 on Ratification of International Covenant and Civil political Rights

\section{Conclusion}

Online Business Training at Jombang House Shelter on children and teenagers can be summarized that children and readas who are there are very interested to open an online business, because they think 
it can be done anywhere whenever, and do not need to look attractive. Of the 7 teenagers in the shleter are all interested in opening an online business.

Advice for the implementation of online business training to launch an online business should install adequate internet network. We recommend that in the stage of more intensive training and duration of a long time so that children and adolescents in Shleter will better understand again how to do business online

\section{References}

Ardila, F., \& Herdiana, I. (2013). Penerimaan diri pada narapidana wanita. Jurnal psikologi kepribadian dan sosial, 2(1), 1-7.

Bauldry, S., Korom-Djakovic, D., McClanahan, W. S., McMaken, J., \& Kotloff, L. J. (2009). Mentoring Formerly Incarcerated Adults: Insights from the Ready4Work Reentry Initiative. Field Report Series. Public/Private Ventures.

Bradley, K. H., Oliver, R. B., Richardson, N. C., \& Slayter, E. M. (2001). No place like home: Housing and the ex-prisoner. Issue brief. Boston, MA: Community Resources for Justice.

Cameron, Brian H and Loreen Butcher-Powell, 2006 ,Gender differences among IT Profesionals in Dealing with Change and skill set Maintenance, Interdisciplinary Journal of Information, knowledge and Management Volume 1

Chornik, K. (2013). Music and Torture in Chilean Detention Centers: Conversations with an Ex-Agent of Pinochet's Secret Police. the world of music, 51-65.

Ciocchini, P. L. (2015). Killing (Life) Time: A study on the Experience of Time in Prision. Sortuz: Oñati Journal of Emergent Socio-Legal Studies, 4(1), 1-33.

Darmanto, 2009, ICT dan Perempuan Usaha Kecil, Asosiasi Pendamping Perempuan Usaha Kecil

Ekasari, A., \& Susanti, N. D. (2009). Hubungan antara optimisme dan penyesuaian diri dengan stress pada narapidana kasus NAPZA di Lapas Kelas IIA Bulak Kapal Bekasi. SOUL, 2(2), 1-32.

Harsono, C. I. (1995). Sistem Baru Pembinaan Narapidana. Djambatan.

Esteban, F., Alós, R., Jódar, P., \& Miguélez, F. (2014). ‘Ex-inmates’ Job Placement. A Qualitive Approach. Revista Española de Investigaciones Sociológicas, 145, 181-204.

Kaplan, C. A. (2006). U.S. Patent No. 7,155,157. Washington, DC: U.S. Patent and Trademark Office.

Martínez-Núñez, M., \& Pérez-Aguiar, W. S. (2014). Efficiency analysis of information technology and online social networks management: An integrated DEA-model assessment. Information \& Management, 51(6), 712-725.

Maruna, S., \& LeBel, T. P. (2012). Revisiting ex-prisoner re-entry: A buzzword in search of a narrative. In Reform and punishment (pp. 170-192). Willan.

Nomor, K. M. K. R. I. M. 02-PK. 04.10 Tahun 1990 tentang Pola Pembinaan Narapidana. Tahanan Menteri Kehakiman Republik Indonesia.

Pradiantiwi, D., Safitri, R. W., \& Prasasti, P. T. A. (2018). CHARACTER EDUCATION FOR PRISONERS SOFT SKILLS TO EMPOWER THROUGH ASINAN TRASI IN THE CORRECTIONAL INSTUTION NGAWI. Research Report.

Purkon, A. (2014). Bisnis online syariah. Gramedia Pustaka Utama.

Rakis, J. (2005). Improving the employment rate of ex-prisoners under parole. Fed. Probation, 69, 7. 
Saragih, H., \& Ramdhany, R. (2012). Pengaruh intensi pelanggan dalam berbelanja online kembali melalui media teknologi informasi forum jual beli (FJB) Kaskus. Jurnal Sistem Informasi, 8(2), 100-112.

Sepúlveda, M. A. (2004). Training in Microenterprise for imprisoned women. Cuadernos Unimetanos, (1), $33-40$.

Shofia, F. (2009). Optimisme masa depan narapidana (Doctoral dissertation, Universitas Muhammadiyah Surakarta)

Suriano, G. (2011). Innovation, Lever For The Reeducation Process And Social Reintegration Of Adult And Juvenile Prisoners. Today's Children are Tomorrow's Parents, 29.

Van Dooren, K., Claudio, F., Kinner, S. A., \& Williams, M. (2011). Beyond reintegration: a framework for understanding ex-prisoner health. International journal of prisoner health, 7(4), 26-36. 